\title{
The Effect of High Temperature on Physical and Mechanical Properties of Self Compacting Lightweight Concretes
}

\author{
Zehra Funda Türkmenoğlu ${ }^{1 *}$, Ahmet Mahmut K1lıç ${ }^{2}$ and Soner Güler ${ }^{3}$
}

\begin{abstract}
In this study, the effects of high temperatures on physical on mechanical properties of self compacting lightweight concretes with marble powder are investigated. To this end, one control and three different types of mixes are prepared and exposed to high temperature with $300 \mathrm{oC}, 600 \mathrm{oC}$, and $900 \mathrm{oC}$ for one hour at the end of 28 days curing. Marble powder is replaced by weight of cement by $10 \%, 15 \%, 20 \%$ and used in mixes as mineral additive. The compressive strength and ultrasonic pulse velocity values are concrete samples under high temperatures are measured and evaluated. As a result, the effect of high temperature on ultrasonic pulse velocity, compressive strength, and surface conditions cannot be ignored.
\end{abstract}

Keywords - Self compacting lightweight concrete, marble powder, ultrasonic pulse velocity, compressive strength, high temperature

\section{INTRODUCTION}

$\mathrm{T}$ $\mathrm{HE}$ use of lightweight concretes is highly popular in the construction sector. Lightweight concrete has superior characteristics compared to conventional concretes such as lightness, high temperature and sound resistance. However, lightweight concretes have low compressive strength and poor workability characteristics. Self compacting concrete (SCC) is a flowable special concrete that does not require vibration for placing and compaction. It is able to flow under its own weight, completely filling formwork and providing full compaction, even in case of congested reinforcement [1].

Today, different types of filler materials are used in self compacting concrete mix to increase durability and strength properties of plain concretes. One of these filler materials is marble powder. Marble powder is a by-product that release during the production of marble processing and the vast majority of them are less than 200 microns. These byproducts release after precipitated by sedimentation method and directly into the field. Thus, using of marble powder in different industrial areas is highly useful in terms of to reduce environmental pollution [2].

\footnotetext{
${ }^{1}$ The Department of Mining Engineering, University of Yüzüncü Yı1, 65080, Van, Turkey, E-mail: fundaturkmenoglu @yyu.edu.tr

${ }^{2}$ The Department of Mining Engineering, University of Çukurova, 65080, Adana, Turkey

${ }^{3}$ The Department of Civil Engineering, University of Yüzüncü Y1l, 65080, Van, Turkey
}

Concrete throughout its service life can be damaged by chemical and physical effect. These chemical and physical effects may lead to some negative results and decrease function and durability of concretes. One of these physical effects is the fire and high temperature. In the case of fire temperature values may rise to $1200 \mathrm{o}$ C. The effects of high temperature on the properties of concrete have been investigated since the middle of the 20 century [3-7]. Physical and mechanical properties can be changed when concretes exposed to high temperature [8]. Affecting of concrete in high temperatures depends on the concrete components, moisture in the beginning conditions, the cement paste, and aggregate type. It can be easily seen the color changes on the concrete surfaces as well as mechanical properties of concretes under high temperature conditions. For example, if the colour of concrete turns into pink or red, it means that the heat is possibly between $300 \mathrm{oC}$ and $600 \mathrm{oC}$. If it is grey, the heat of concrete is between $600 \mathrm{oC}$ and $900 \mathrm{oC}$ [9-10].

In this study, the effects of high temperature on the loss of unit weight, ultrasonic pulse velocity, and compressive strength of self compacting concretes with marble powder are investigated and discussed.

\section{II.EXPERIMENTAL PROGRAM}

In all of mixes, CEM I $42.5 \mathrm{~N}$ Portland cement, pumice with maximum aggregate size of $8 \mathrm{~mm}$, marble powder and superplasticizer are used according to Turkish Standard TS EN 197-1 [11]. The specific gravity and specific area of cement 3.09 and $3865 \mathrm{~cm} 2 / \mathrm{g}$, respectively. Pumices obtained from Van (Erçiş-Kocapınar) areas with the size of 0-2 mm (A1), 2-4 mm (A2), and 4-8 mm (A3) are used in concrete mixes. The specific gravities of $\mathrm{A} 1, \mathrm{~A} 2$, and $\mathrm{A} 3$ aggregates is $1.72,1.32$ and 1.06 , respectively. The unit weights of pumice aggregates are obtained as $636 \mathrm{~kg} / \mathrm{m} 3,495 \mathrm{~kg} / \mathrm{m} 3$, and 413 $\mathrm{kg} / \mathrm{m} 3$, respectively. The marble powder is supplied from Malaylar Mermer A.Ş. that is located in Van organized industrial site. The marble powder used in all concrete mixes is dryed at $105 \mathrm{oC}$ in drying oven before using in concrete mixes. The specific gravity of marble powders is 2,61 . Several design procedure based on scientific theories or empiritical experience have been proposed for normal SCC. In this study, all mix design of self compacting lightweight concrete have been done according to ACI 211.2-98 [12] and ACI 237R-07 [13] design codes. One control and three different mixes are 
prepared and tested. Marble powder is replaced by cement of weight by $0 \%, 10 \%, 15 \%$, and $20 \%$ ratios. The ratios of water/cement in all mixes are kept as 0.63 . The concrete mix proportions are given in Table 1.

TABLE I

Mix Proportions Of SELF COMPACTING Lightweight CONCRETE FoR $1 \mathrm{M}^{3}$

\begin{tabular}{|c|c|c|c|c|c|c|c|c|}
\hline $\begin{array}{c}\text { Mix } \\
\text { description }\end{array}$ & $\begin{array}{l}\mathrm{W} / \mathrm{C} \\
(\%)\end{array}$ & $\begin{array}{c}\text { Binder } \\
\left(\mathrm{kg} / \mathrm{m}^{3}\right)\end{array}$ & $\begin{array}{c}\text { Water } \\
\left(\mathrm{kg} / \mathrm{m}^{3}\right)\end{array}$ & $\begin{array}{l}\text { Cement } \\
\left(\mathrm{kg} / \mathrm{m}^{3}\right)\end{array}$ & $\begin{array}{l}\text { Marble } \\
\text { Powder } \\
\left(\mathrm{kg} / \mathrm{m}^{3}\right)\end{array}$ & $\begin{array}{l}\text { Fine } \\
\text { aggregate } \\
(0-2 \mathrm{~mm}) \\
\left(\mathrm{kg} / \mathrm{m}^{3}\right)\end{array}$ & $\begin{array}{c}\text { Fine } \\
\text { aggregate } \\
(2-4 \mathrm{~mm}) \\
\left(\mathrm{kg} / \mathrm{m}^{3}\right)\end{array}$ & $\begin{array}{c}\text { Coarse } \\
\text { aggregate } \\
(4-8 \mathrm{~mm}) \\
\left(\mathrm{kg} / \mathrm{m}^{3}\right)\end{array}$ \\
\hline Control & 0.625 & 500 & 312.5 & 500 & 25 & 455.599 & 157.683 & 143.140 \\
\hline MP10 & 0.625 & 500 & 312.5 & 450 & 50 & 452.948 & 157.765 & 142.307 \\
\hline MP15 & 0.625 & 500 & 312.5 & 425 & 75 & 451.602 & 157.300 & 141.885 \\
\hline MP20 & 0.625 & 500 & 312.5 & 400 & 100 & 450.255 & 155.834 & 141.462 \\
\hline
\end{tabular}

In order to investigate the effects of high temperatures on self compacting concretes, cube samples with the dimensions of 10x10x10 cm are produced. As seen in Fig.1, after 28 days curing conditions, cube samples are exposed to Protherm HLF 150 oven with the capacity of $1200 \mathrm{oC}$ for one hour at $300 \mathrm{oC}$, $600 \mathrm{oC}$, and $900 \mathrm{oC}$. Three samples for each mixes are tested under each heating values. The oven is runned for one hour at target temperature and after automatically closed. Afterwards, the cube samples are allowed to cooling. Then, loss of unit weights, ultrasonic pulse velocity, and compressive strength of cube samples are determined. Hydraulic press with 3000 $\mathrm{kN}$ capacity is used to determine compressive strength of concrete samples. Compressive strength tests are performed according to Turkish Standard TS EN 12390-3 [14]. The Ultrasonic pulse velocity tester PULSONIC equipment that consist of the ultrasonic tester 58 E-48, two transducers, one transmitter and one receiver head $54 \mathrm{kHz}$ type, two connecting cables, and two $1.5 \mathrm{~V}$ alkaline $\mathrm{D}$ type batteries are used to measure UPV of cube concrete samples. The ultrasonic pulse velocity tests are performed according to ASTM C 597-83[15]. The setup for measuring UPV of concrete is shown in Fig. 2.

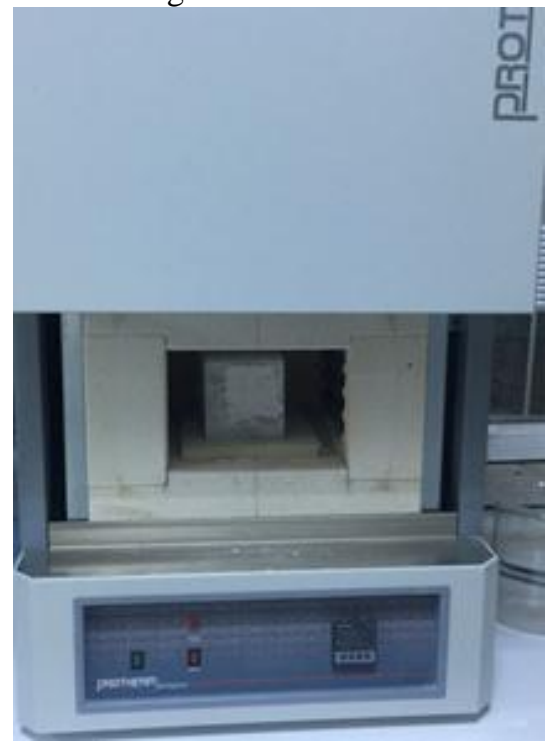

Fig. 1: High temperature oven

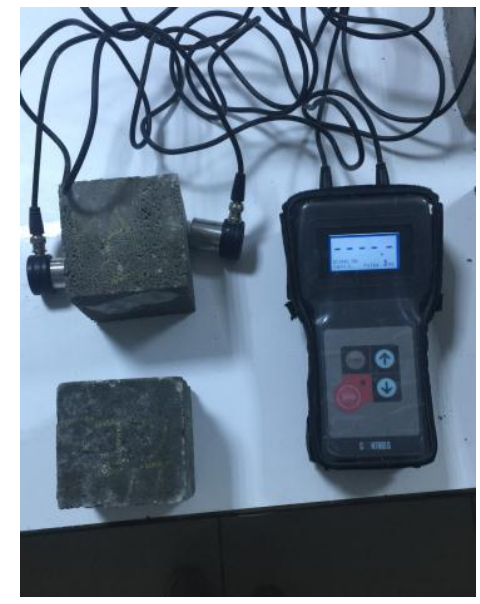

Fig. 2: UPV device

\section{TeSt RESUlts}

\subsection{High Temperature Effects on Surface Properties of Concrete}

As seen in Fig.3, some color changes happens on surface of self compacting lightweight concrete samples due to high temperature effects. As a result of these color changes, it can be easily estimated the range of temperature values. The color changes on concrete samples are much more apparent for the ones with siliceous river aggregates. The views of concrete samples exposed to high temperatures are seen in Fig.3.

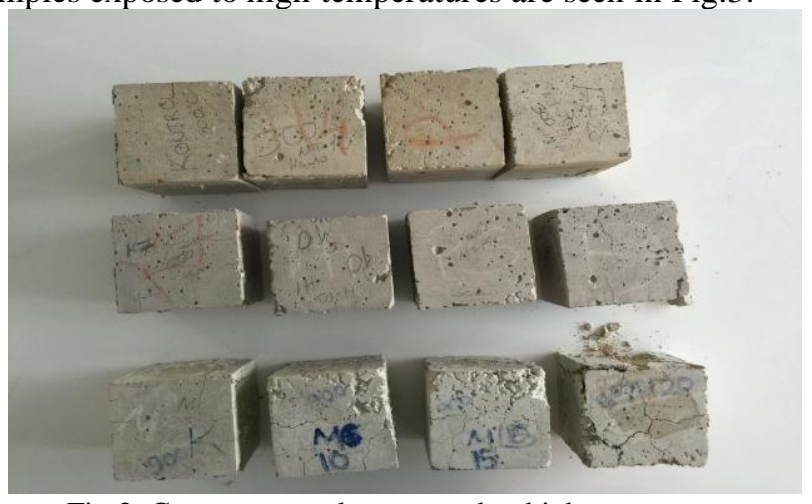

Fig 3. Concrete samples exposed to high temperature 
As seen in Fig.3, it can be seen that cracking, rupture, and color changes happened much more in the concrete samples exposed to $900^{\circ} \mathrm{C}$ than the ones with $300^{\circ} \mathrm{C}$ and $600^{\circ} \mathrm{C}$.

\subsection{High Temperature Effects on Loss of Unit Weights of} Concretes

Unit weights of self compacting lightweight concrete samples are decreased due to high temperature effect. The loss of unit weights of concrete samples is given in Table 2 .

TABLE II

LOSS OF UNIT WEIGHTS OF CONCRETES EXPOSED TO HIGH TEMPERATURE

\begin{tabular}{ccc}
\hline \hline $\begin{array}{c}\text { Mixture } \\
\text { code }\end{array}$ & $\begin{array}{c}\text { Temperatur } \\
\mathrm{e} \\
\left({ }^{\circ} \mathrm{C}\right)\end{array}$ & $\begin{array}{c}\text { Loss of } \\
\text { unit weight } \\
(\%)\end{array}$ \\
\hline & & \\
Control & 300 & 1.75 \\
Control & 600 & 7.58 \\
Control & 900 & 9.60 \\
$10 \mathrm{MP}$ & 300 & 1.57 \\
$10 \mathrm{MP}$ & 600 & 7.11 \\
$10 \mathrm{MP}$ & 900 & 10.7 \\
$15 \mathrm{MP}$ & 300 & 1.52 \\
$15 \mathrm{MP}$ & 600 & 7.08 \\
$15 \mathrm{MP}$ & 900 & 10.3 \\
$20 \mathrm{MP}$ & 300 & 1.95 \\
$20 \mathrm{MP}$ & 600 & 9.2 \\
$20 \mathrm{MP}$ & 900 & 11.5 \\
\hline \hline
\end{tabular}

It is seen that unit weights of all concrete samples decrease after high temperature effects. Loss of unit weights of concrete samples with exposed to $300 \mathrm{oC}$ is between $1.52 \%$ and $1.95 \%$, the ones with exposed to $600 \mathrm{oC}$ is between $7.08 \%$ and $9.02 \%$, and the ones with exposed to $900 \mathrm{oC}$ is between $9.6 \%$ and $11.5 \%$. The most decrease in compressive strength is obtained for concrete with $20 \%$ replacement of cement with marble powder at $900 \mathrm{oC}$ temperature.

\subsection{High Temperature Effects on Ultrasonic Pulse Velocity}

The effects of high temperature on the ultrasonic pulse velocity of self compacting lightweight concretes are given in Table 3. As seen in Table 3, it is observed to decrease in ultrasonic pulse velocity values when temperature effect increases.

TABLE III

Ultrasonic Pulse Velocity VAlue Of ConcRetes EXPosed To High TEMPERATURE

\begin{tabular}{ccc}
\hline \hline Mixture code & $\begin{array}{c}\text { Temperature } \\
\left({ }^{\circ} \mathrm{C}\right)\end{array}$ & $\begin{array}{c}\text { Ultrasonic pulse } \\
\text { velocity }(\mathrm{km} / \mathrm{sn})\end{array}$ \\
\hline \hline Control & 300 & 4.11 \\
$10 \mathrm{MP}$ & 300 & 4.20 \\
$15 \mathrm{MP}$ & 300 & 4.23 \\
$20 \mathrm{MP}$ & 300 & 3.96 \\
Control & 600 & 2.34 \\
$10 \mathrm{MP}$ & 600 & 2.41 \\
$15 \mathrm{MP}$ & 600 & 2.58 \\
$20 \mathrm{MP}$ & 600 & 2.20 \\
Control & 900 & 1.68 \\
$10 \mathrm{MP}$ & 900 & 1.72 \\
$15 \mathrm{MP}$ & 900 & 1.76 \\
$20 \mathrm{MP}$ & 900 & 1.63 \\
\hline \hline
\end{tabular}

\subsection{High Temperature Effects on Compressive Strength}

The effects of high temperature on the compressive strength of self compacting lightweight concretes are given in Table 4. As seen in Table 4, the biggest difference in ultrasonic pulse velocity values compared to control samples is for the concretes with $20 \%$ replacement of cement with marble powder at $900 \mathrm{oC}$ temperature.

TABLE IV

MECHANICAL PROPERTIES OF SELF COMPACTING LIGHTWEIGHT CONCRETE MIXTURES

\begin{tabular}{cccc}
\hline $\begin{array}{c}\text { Mixture } \\
\text { code }\end{array}$ & $\begin{array}{c}\text { Temperatur } \\
\text { e } \\
\left({ }^{\circ} \mathrm{C}\right)\end{array}$ & $\begin{array}{c}\text { Compressive } \\
\text { strength of } \\
\text { concrete }(\mathrm{MPa})\end{array}$ & $\begin{array}{c}\text { Loss of } \\
\text { strength }(\%)\end{array}$ \\
\hline Control & 20 & 27.68 & - \\
Control & 300 & 24.17 & 12.68 \\
Control & 600 & 19.85 & 28.28 \\
Control & 900 & 8.05 & 70.91 \\
MP10 & 20 & 28.25 & - \\
MP10 & 300 & 25.29 & 10.47 \\
MP10 & 600 & 20.35 & 27.96 \\
MP10 & 900 & 8.65 & 69.38 \\
MP15 & 20 & 30.03 & - \\
MP15 & 300 & 26.44 & 11.95 \\
MP15 & 600 & 21.34 & 28.93 \\
MP15 & 900 & 9.15 & 69.53 \\
MP20 & 20 & 25.79 & - \\
MP20 & 300 & 22.07 & 14.47 \\
MP20 & 600 & 18.73 & 27.37 \\
MP20 & 900 & 6.85 & 73.43 \\
& & & \\
\hline \hline
\end{tabular}

\section{CONCLUSION}

This paper presents the results of experimental study on physical and mechanical properties of lightweight self compacting concretes. Following findings are reached as a result of this study.

- The effect of high temperature especially at $900 \mathrm{oC}$ on concrete samples in terms of compressive strength, ultrasonic pulse velocity, and surface changes are very significant.

- Cracking, rupture, and color changes on concrete surfaces happened much more in the concrete samples with exposed to $900 \mathrm{oC}$ than the ones at $300 \mathrm{oC}$ and $600 \mathrm{oC}$.

- The biggest difference in compressive strength between control samples and concrete with $20 \%$ replacement of cement with marble powder is $73.43 \%$.

- The increase in compressive strength and ultrasonic pulse velocity values is only valid for concrete samples with up to $15 \%$ replacement of cement with marble powder. These values are smaller for concrete samples with $20 \%$ replacement of cement with marble powder than the control ones.

\section{REFERENCES}

[1] EFNARC, "The European guidelines for self-compacting concrete, Specification, Production and Use," Association House, UK, 2005. 
[2] A.A. Aliabdo, A.E. Elmoaty, and E.A. Auda, "Re-use of waste marble dust in the production of cement and concrete," Construction and Building Materials, vol. 50, pp. 28-41, 2014. http://dx.doi.org/10.1016/j.conbuildmat.2013.09.005

[3] H. Tanyıldızı, and A. Çoşkun, "The effect of high temperature on compressive strength and splitting tensile strength of structural lightweight concrete containing fly ash," Construction and Building Materials, vol. 22, pp. 2269-2275, 2008. http://dx.doi.org/10.1016/j.conbuildmat.2007.07.033

[4] N. Yaltay and C.E. Ekinci, "Investigation of compression strength of lightweight concrete, subjected to elevated temperature, produced with pumice aggregate and colemanite addition by non-destructive method," SDU International Technologic Science, vol.5, pp. 30-41, 2013.

[5] Z.P. Bazant, M.F. Kaplan, "Concrete at high temperatures, Material Properties and Mathematical Models, Longman Group, England, ISBN 0582- 08624-4, 1996.

[6] A. Savva, P. Manita, K.K. Sideris, "Influence of elevated temperatures on the mechanical properties of blended cement concretes prepared with limestone and siliceous aggregates," Cement and Concrete Composites, vol. 27:2,pp. 239-248, 2005. http://dx.doi.org/10.1016/j.cemconcomp.2004.02.013

[7] I. Netinger, I. Kesegic and I. Guljasn, "The effect of high temperatures on the mechanical properties of concrete made with different types of aggregates" Fire Safety Journals, vol.46, pp.425-430, 2011. http://dx.doi.org/10.1016/j.firesaf.2011.07.002

[8] D.J. Naus, "The Effect of Elevated Temperature on Concrete Materials and Structures," USA Regulatory commission office of nuclear regulatory research under interagency agreement, No 186-N674-1Y.

[9] C. Andrade, C. Alonso, and G.A. Khoury, "Relating Microstructure to Properties Course on Effect of Heat on Concrete," International Centre for Mechanical Sciences (CISM), Italy, 2003.

[10] A.M. Neville, Properties of Concrete 4th ed. Longman Scientific and Technical, USA, New York, 2000, pp. 581-585.

[11] TS EN 197-1. "Cement Part 1: Composition and Conformity Criteria for Common Cement", Turkish Standard, Turkey (in Turkish), 2002.

[12] ACI Committee 211.2 "Standart Practice for selecting proportions for structural lightweight concrete" American Concrete Institute, Farmington Hills, Mich., 1987, 27 pp.

[13] ACI Committee 237R, "Self Consolidating Concrete", American Concrete Institute, Farmington Hills, Mich., 2007, 27 pp.

[14] TS EN 12390-3, "Testing Hardened Concrete - Part 3: Compressive Strength of Test Specimens", Turkish Standard, Turkey (in Turkish), 2003.

[15] ASTM C597, "Standard Test Method for Pulse Velocity through Concrete". Standard ASTM C597-83, American Society for Testing Materials, Philadelphia, 2002. 